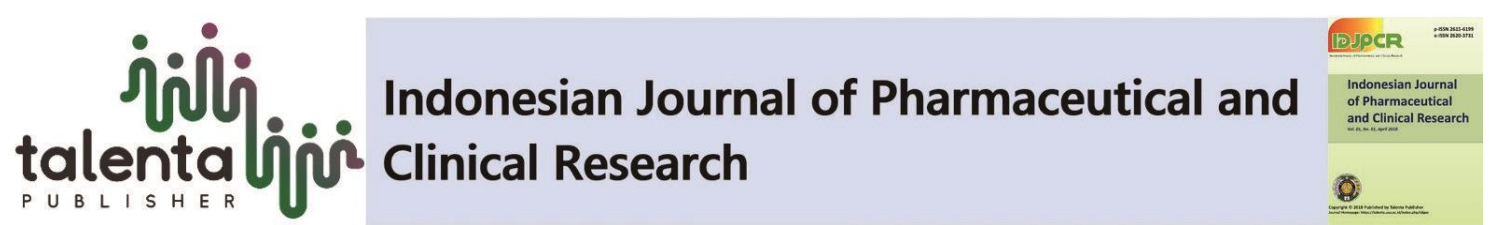

\title{
Antimicrobial Activity of Liquid Soap Containing Turmeric (Curcuma domestica Val.) and Lemongrass (Cymbopogon nardus L.) Leaf Juice
}

\author{
Nazliniwaty ${ }^{*}$ Erly Sitompul ${ }^{1}$ \\ ${ }^{1}$ Faculty of Pharmacy, Universitas Sumatera Utara, \\ Padang Bulan, Medan 20155, Indonesia
}

\begin{abstract}
The purpose of this study was to formulate an antimicrobial liquid soap containing $25 \%$ turmeric and lemongrass leaf juice. Lemongrass leaf juice and turmeric juice $25 \%$ were formulated into a liquid soap. Stability, $\mathrm{pH}$ and viscosity of the liquid soap were evaluated. For stability tests, the preparation was stored for 3 months at room temperature. The $\mathrm{pH}$ test was measured by Hanna $\mathrm{pH}$ meter. The viscosity test, was measured by Brookfield viscometer. The antimicrobial activity of the liquid soap was measured by disc diffusion method using bacteria such as Staphylococcus epidermis, Eschericia coli, Microsporum gypseum and Candida albicans. Physical properties of the formulated liquid soap including $\mathrm{pH}$, viscosity, and stability showed that it was stable for 3 months. The results of antimicrobial test of the liquid soap containing turmeric and lemongrass leaf juice showed that the inhibition diameter against Staphylococcus epidermis, Escheceria coli, Microsporum gypseum and Candida albicans were 22.89, $27.05,24.30$, and $33.05 \mathrm{~mm}$, respectively, while the liquid soap without the juice were $20.76,19.50,20.50$ and $21.46 \mathrm{~mm}$, respectively. The soap was effective in inhibiting the growth of microbes. Combination of turmeric and lemongrass leaf juice increased the inhibitory zone diameter of the liquid soap for microbe.
\end{abstract}

Keywords: Antimicrobial Agent, Lemongrass Leaf, Liquid Soap, Turmeric Leaf.

\begin{abstract}
Abstrak. Penelitian ini bertujuan untuk memformulasi sabun cair antibakteri yang mengandung $25 \%$ air perasan daun kunyit dan daun sereh. Pengujian sifat fisika kimia sabun dilakukan terhadap stabilitas, $p H$, dan viskositas. Untuk pengujian stabilitas, sediaan disimpan selama 3 bulan pada suhu ruang. Pengujian $p H$ dilakukan dengan menggunakan pH meter Hanna. Viskositas diukur menggunakan viskometer Brookfield. Pengujian aktivitas antimikroba terhadap Staphylococcus epidermidis, Eschericia coli, Microsporum gypseum dan Candida albicans dilakukan dengan metode difusi agar menggunakan pencadang kertas. Sifat fisika kimia sabun yang dihasilkan stabil selama 3 bulan. Hasil pengujian antimikroba dari sabun cair yang mengandung air perasan daun kunyit dan daun sereh stabil menunjukkan diameter hambatan terhadap Staphylococcus epidermis, Eschericia coli, Microsporum gypseum dan Candida albicans adalah 22,89, 27,05, 24,30, dan 33,05 mm secara berurutan, sedangkan yang tidak mengandung air perasan daun kunyit dan daun sereh menunjukkan diameter hambat sebesar 20,76, 19,50, 20,50 dan 21,46 mm secara berurutan. Sabun cair yang dihasilkan efektif dalam
\end{abstract}

${ }^{*}$ Corresponding author at: Universitas Sumatera Utara, Medan, Indonesia

E-mail address: nazliniwaty@usu.ac.id 
menghambat pertumbuhan mikroba. Kombinasi air perasan daun kunyit dan daun sereh meningkatkan diameter zona hambat dari sabun cair yang dihasilkan.

Kata kunci: Candida albicans, daun kunyit, daun sereh, Eschericia coli, Microsporum gypseum, Sabun cair, Staphylococcus epidermidis.

Received 17 May 2017 | Revised 19 October 2017 | Accepted 12 March 2018

\section{Introduction}

Turmeric (Curcuma domestica val.) is one of rhizomatous plants included into Zingiberaceae family. It has a pseudo stems formed from the leaf sheaths. The height of the plant can reach up to 1.0 to 1.5 meters. It forms clumps like shrubs and clustered. The leaves are single, wide lanceolate in shape, flat brimmed, tapered tip base, pinnate, flaccid and light green in color. The main compounds found in turmeric are curcuminoids (3.0-5.0\%) and essential oil (2.5-6.0\%) [1]. The plant has been used as traditional medicine in many countries because of the antibiotic and antiseptic effects of curcumin contained in the plant, an important constituent of turmeric. A yellow-pigmented fraction isolated from the rhizomes of Curcuma contains curcuminoids belonging to the dicinnamoyl methane group. Curcuminoids are present to the extent of 3-5\%. It is an important active ingredient responsible for the biological activity of Curcuma. Though the major activity is anti inflammatory, it has also been reported to possess antioxidat, anti allergic, wound healing, anti bacterial, anti fungal and anti tumor activity [2].

Lemongrass (Cymbopogon nardus L.), Poaceae family, is herbaceous, has pseudo stems consisting of flat leaf sheats with $20-60 \mathrm{~cm}$ long, parallel, ribbon shape, thin and smooth hairy, has an aromatic smell because of its essential oil consisting of geraniol and sineol which are antiseptic. It is widely used for seasoning and cold medicine [3]. Lemongrass extracts showed important therapeutic potentials such as anti-cancer, antihypertensive and anti-mutagenicity. Others include non-toxic properties, anti-diabetic, anti-oxidant, anxiolytic, anti-nociceptive and anti-fung [4].

Previous research has been conducted to examine the phenol coefficient of plants containing essential oils [5]. These compounds can kill bacteria and fungi thus are antiseptic or antibacterial ${ }^{6}$. The utilization of juices of kaffir lime, lemongrass and basil leaves have been also investigated for antibacterial activity against Salmonellathypi and Staphylococcus aureus [6].

Based on these tradisional used and previous researchs tings above, we conducted this study of juices of leaves containing essential oils which are turmeric (Labiatae) and lemongrass leaves (Poaceae) formulated into liquid soap with concentration of each juice was $25 \%$. Microbial test were Staphylococcus epidermis, Eschericia coli, Microsporum gypseum, and Candida albicans. 


\section{Materials And Methods}

\subsection{Materials}

The materials used in this study were Nutrient Broth (Oxoid), Nutrient Agar (Oxoid), Potato Dextrose Agar (Oxoid), sterile distilled water, sterile $\mathrm{NaCl} 0.9 \%$, turmeric leaves juice $25 \%$ and lemongrass leaves juice 25\%, and liquid soap. The samples (turmeric and lemongrass) were taken from sub-district of Padang Bulan Selayang II Medan.

\subsection{Preparation of Juices from Turmeric and Lemongrass Leaves at Concentration of $25 \%$}

Turmeric leaves were sliced or cut thinly, and then crushed in a mortar until smooth. Twenty five grams of the leaves were weighed using an electric scales, put in to $100 \mathrm{ml}$ volumetric flask. Sterile distilled water was added up to the mark line. Then, the volumetric flask was closed and stored in a refrigerator for 24 hours. The next step was to filter it using a filter paper so that the juice with concentration of $25 \%$ was obtained. The same procedure was carried out for lemongrass leaves.

\subsection{Preparation of Liquid Soap}

The liquid soap formula used in this study was modified based on a formula used in a previous study [8].

$\begin{array}{ll}\text { R/ Olive oil } & 15 \\ \text { Potassium hydroxide } & 8 \\ \text { Carboxy methyl cellulose } & 0.5 \\ \text { Sodium lauryl sulfate } & 0.5 \\ \text { Stearic acid } & 0.25 \\ \text { Butyl hydroxy anisole (BHA) } & 0.5 \\ \text { Parfume } & 1 \\ \text { Disstiled water } & \text { up to } 50 \mathrm{ml}\end{array}$

A. Modified formula

$\mathrm{R} /$ Sodium lauryl sulfate

Hydroxy propyl methyl cellulose

(HPMC)

Glycerin

Tween 80

Turmeric juice

Lemongrass juice

Disstiled water

up to $100 \mathrm{ml}$ 
Twenty grams of sodium lauryl sulfate was dissolved in $25 \mathrm{ml}$ of turmeric leaf juice (mixture A). As much as 2.5 grams of HPMC was weighed and then poured in to $25 \mathrm{ml}$ of lemongrass leaves juice and allowed to expand for about 15 minutes. Glycerin was gradually added into expanded HPMC while stirred until homogen. Later, Tween 80 was added and stirred to obtain a homogeneous mixture (mixture B). Mixture A was poured slowly into mixture B, and stirred until the mixture was homogen. If necessary, it could be heated in a water bath, then added with distilled water.

\subsection{Physical Properties of the Preparations}

\section{A. Physical Stability}

Physical stability of the preparation examined including consistency, color, and odor. Preparation was stable if its color, odor and consistency were not changed visually during storage, and also not over grown by fungus.

\section{B. Determination of $\mathrm{pH}$}

Determination of $\mathrm{pH}$ of preparation was done by using Hanna $\mathrm{pH}$ meter. The instrument was first calibrated using standard neutral $\mathrm{pH}$ buffer solution $(\mathrm{pH}$ 7.01) and acidic $\mathrm{pH}$ buffer solution (pH 4.01) until showed $\mathrm{pH}$ values. Then the electrode was washed with distilled water, and dried using tissue paper. Samples were made at concentration 1\% (1 gram preparation was weighed and dissolved in $100 \mathrm{ml}$ distilled water). Then the electrode was dipped into the sample solution until the instrument showed a constant $\mathrm{pH}$ value. The number appeared in $\mathrm{pH}$ meter was the $\mathrm{pH}$ value of preparations.

\section{Determination of Viscosity}

Viscosity of the preparation was examined by using the Brookfield viscometer. Procedure: Spindle 63 was attached to viscometer and put into the preparation to the limit line. The motor was switched on at speed 3 so spindle was rotated. The measurement was considered finished if the needle indicated a constant number. The viscosity was obtained by multiplying the readable numbers with a factor of 100 .

\subsection{Preparation of Inoculum}

\section{A. Preparation of Culture Stocks}

The bacterial colonies were taken with sterile loop, and then inoculated in slanting NA medium by scratching the loop gently up the surface of NA. Then it was incubated in the incubator at $37^{\circ} \mathrm{C}$ for 24 hours. The same procedure was applied for Staphylococcus epidermis and Eschericia coli. The fungal colonies were taken using a sterile loop, and then inoculated in slanting PDA medium by scratching the loop gently up the surface of PDA. Then it was incubated in the incubator at $25^{\circ} \mathrm{C}$ for 48 hours. This applied to Microsporum gypseum and Candida albicans. 


\section{B. $\quad$ Preparation of Inoculum}

The bacterial colonies were taken from culture stocks with a sterile loop and suspended in a test tube containing $10 \mathrm{ml} \mathrm{NB}$. Then the turbidity of the solution was measured at wavelength 560 nm until obtained 25\% transmittance. This applied to Staphylococcus epidermis and Eschericia coli. The fungal colonies were taken from culture stocks with a sterile loop and suspended in a test tube containing $10 \mathrm{ml} \mathrm{NaCl} 0.9 \%$. Then the turbidity of the solution was measured at wavelength $580 \mathrm{~nm}$ until obtained 25\% transmittance. This applied to Microsporum gypseum and Candida albicans.

\section{Antimicrobial Activity of the Liquid Soap Containing Juices of Turmeric and Lemongrass Leaves}

Antimicrobial activity of the liquid soap containing juices of turmeric and lemongrass leaves was evaluated by agar diffusion method using a paper petri dish. As much as $0.1 \mathrm{ml}$ of bacterial inoculums was mixed homogeneously with $15 \mathrm{ml}$ of NA in the petri dish, then the medium was allowed to be solid. A paper disk was dipped into the sample for 15 minutes, and attached to the solid agar medium. Then it was incubated at $37^{\circ} \mathrm{C}$ for 24 hours. Next, the clear zone diameter around disk was measured using calipers. The test was performed 3 times. This procedure was also applied to Staphylococcus epidermis and Eschericia coli.

As much as $0.1 \mathrm{ml}$ of bacterial inoculums was mixed homogeneously with $15 \mathrm{ml}$ of NA in the petri dish, then allowed the medium to be solid. Paper disk was dipped into the sample for 15 minutes, and attached to the solid agar medium. Then it was incubated at $25^{\circ} \mathrm{C}$ for 48 hours. Next, the diameters of the clear zones around the petri disks were measured using calipers. The test for each disk was performed 3 times. This procedure applied to Microsporum gypseum and Candida albicans.

\section{Results}

\subsection{Physical Properties of the Preparations}

Results of the physical properties of the liquid soap containing juices of turmeric and lemongrass leaves are demonstrated in Table 1 . The present study indicated that physical properties of preparations were stability, $\mathrm{pH}$ and viscosity. During 3 months of storage, the liquid soaps were stable; no change was obtained in terms of consistency, color and odor, $\mathrm{pH}$, and viscosity as shown in Table 1.

\subsection{Antimicrobial Activity of the Liquid Soap Containing Juices of Turmeric and Lemongrass Leaves}

The results of the antimicrobial activity test showed that the liquid soap containing turmeric and lemongrass leaves juices can inhibit the growth of Staphylococcus epidermis, Eschericia coli, Microsporum gypseum and Candida albicans. 
Table 1. Physical Properties of the Liquid Soap Containing Juics of Turmeric and Lemongrass

\begin{tabular}{lcc}
\multicolumn{2}{c}{ Leaves } \\
\hline Shape & Liquid soap & Liquid soap without extract \\
Color & greenish brown & liquid \\
Odor & aroma of turmeric and lemongrass & clear \\
$\mathrm{pH}$ & 6.9 & - \\
Viscosity & $500 \mathrm{cp}$ & $2000 \mathrm{cp}$ \\
\hline
\end{tabular}

Table 2. Antimicrobial Activity of Liquid Soap Containing Turmeric and Lemongrass Leaves Juices

\begin{tabular}{lcc}
\hline & \multicolumn{2}{c}{ Inhibitory Zone Diameter $(\mathbf{m m})^{*}$} \\
\cline { 2 - 3 } & Liquid soap & Liquid soap without extract \\
\hline S. epidermis & 22.87 & 20.76 \\
E. coli & 27.05 & 19.5 \\
M. gypseum & 24.3 & 20.5 \\
C. albicans & 33.05 & 21.46 \\
\hline
\end{tabular}

${ }^{*}=$ average of three times measurements

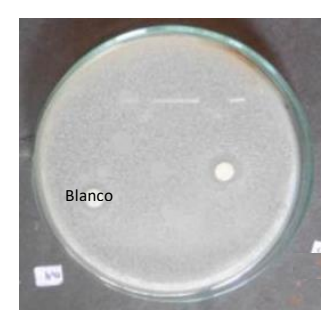

$\mathbf{a}$

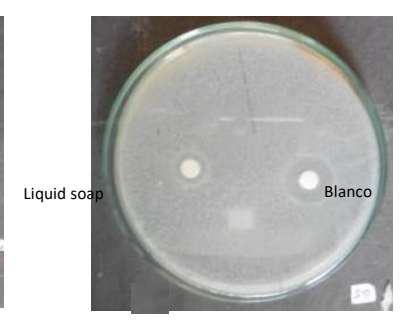

b

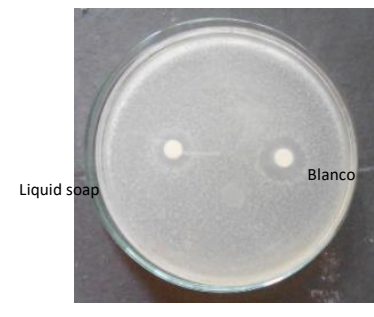

c

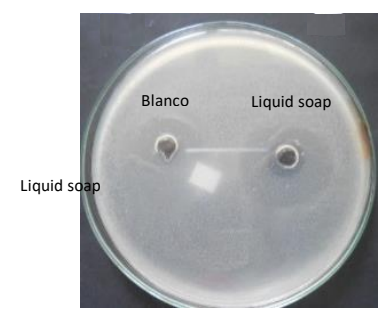

d

Figure 1. Inhibitory Zone Diameter of the Liquid Soap Containing Juices of Turmeric And Lemongrass Leaves Against (a) Staphylococcus epidermis, (b) Eschericia coli, (c) Microsporum gypseum and (d) Candida albicans

\section{Discussion}

Based on Table 1, the viscosity of liquid soap without extract was more viscous than the liquid soap containing juices of turmeric and lemongrass leaves. The viscosity decreased due to the addition of the extract into the liquid soap formula.

Based on the Table 2, it could be seen that liquid soap containing turmeric and lemongrass leaves juices had a great inhibition against all microbes. According to Indonesian Pharmacopeia Fourth edition, effective inhibition as an antimicrobial is $14-16 \mathrm{~mm}$. This liquid soap was more effective to inhibit microbial test growth of Candida albicans with inhibitory zone diameter $33.05 \mathrm{~mm}$ than Staphylococcus epidermis, Eschericia coli, and Microsporum gypseum. 
A previous study Research done by Nurbaya (2014) showed that mixture of the juices of turmeric and lemongrass leaves with each concentration of $25 \%$ provided synergistic effect in inhibiting Salmonella thypi and Staphylococcus aureus.

\section{Conclusion}

Liquid soap containing juices of turmeric and lemongrass leaves with concentrations of $25 \%$ demonstrated antibacterial activity indicated from the presence of inhibitory zone of more than $14 \mathrm{~mm}$. The most effective inhibition of the liquid soap was on Candida albicans with inhibitory zone diameter of $33.05 \mathrm{~mm}$ compared to other microbes tested.

\section{Acknowledgements}

We would like thank to Faculty of Pharmacy, University of Sumatera Utara for supporting this project.

\section{REFERENCES}

[1] S.Y.Hartati, Balittro, "The use of turmeric as traditional medicine and other benefits. Research and development of industrial plants", vol. 19, no.2, pp. 5-9. 2013

[2] A.D. Pandey, S.K. Katiyar, "Determination and comparison of the curcuminoid pigments in turmeric genotypes (Curcuma domestica Val) by high-performance liquid chromatography", International Journal of Pharmacy and Pharmaceutical Sciences, vol. 2, pp. 125-127. 2010.

[3] Department of Health Republic of Indonesia, The use of medicinal plants, Third ed. Directorate Jeneral of Drug and Food Surveillance, Jakarta, 1983.

[4] S.K. Olorunnisola, A.M. Hammed, S. Simsek. Biological properties of lemongrass: Anoverview. International Food Research Journal, vol. 121, no.2. 2014

[5] Department of Health Republic of Indonesia, Materia Medika Indonesia, Sixth ed. Directorate Jeneral of Drug and Food Surveillance, Jakarta, 1989

[6] S.Nurbaya, E. Sitompul, and Suryanto, "Test of phenol coefficient from plants' leaves containing volatile oils". National Seminar in Biology. 2013.

[7] Behura S, Srivastava VK. "Essential oils of leaves of Curcuma species". Journal of Essential Oil Research. Vol.1, no.16(2), pp.109-10. Mar 2004

[8] J.C. Kasenda, P. Yamlean, and W.A. Lolo, "Formulation and test of antibacterial activity of liquid soap containing ethanolic extract of Acalypha hispida Burm.F leaf toward the growth of Staphylococcus aureus". Jurnal Ilmiah Farmasi UNSRAT. Vol. 5(3), pp. 40-47. 2016

[9] S.Nurbaya, E. Sitompul, and Suryanto, Test of antibacterial activities of juices of lemongrass, citrus, and basil leaves, and their combinations. National Seminar in Biology. 2014. 